\title{
Comparison of in vivo effect of inorganic lead and cadmium on glutathione reductase system and $\delta$-aminolevulinate dehydratase in human erythrocytes
}

\author{
H. A. ROELS ${ }^{1}$, J. P. BUCHET 1 , R. R. LAUWERYS ${ }^{1}$ and J. SONNET ${ }^{2}$ \\ Industrial and Medical Toxicology Unit, Louvain University, Avenue Chapelle-aux-Champs 4, \\ B-1200 Brussels, Belgium¹, and Unité de Biochimie Mêdicale, Louvain University, Cliniques \\ Universitaires St-Pierre, Brusselsestraat 69, B-3000 Louvain, Belgium²
}

Roels, H. A., Buchet, J. P., Lauwerys, R. R., and Sonnet, J. (1975). British Journal of Industrial Medicine, 32, 181-192. Comparison of in vivo effect of inorganic lead and cadmium on glutathione reductase system and $\delta$-aminolevulinate dehydratase in human erythrocytes. The activity of $\delta$-aminolevulinate dehydratase (ALAD) of erythrocytes, the lead (Pb-B) and cadmium (Cd-B) concentration in whole blood, the content of reduced glutathione (GSH) in erythrocytes, and the regeneration rate of GSH by intact erythrocytes were measured during an epidemiological survey of 84 men employed in a Belgian cadmium and lead producing plant. A control group of 26 persons (students and laboratory staff) was also examined.

The logarithm of the ALAD activity is highly inversely correlated with $\log \mathrm{Pb}-\mathrm{B}$ $(r=-0.760)$ but no correlation was found with $\log \mathrm{Cd}-\mathrm{B}$. There exists a significant negative correlation between GSH and $\log \mathrm{Pb}-\mathrm{B}(\mathrm{r}=-0.423)$ but not between GSH and $\log \mathrm{Cd}-\mathrm{B}$. The apparently good relationship between $\log$ ALAD and GSH disappeared completely by holding $\log \mathrm{Pb}-\mathrm{B}$ constant, but $\log$ ALAD remained highly inversely correlated with $\log \mathrm{Pb}-\mathrm{B}$ when standardized for GSH concentration $(r=-0 \cdot 748)$.

In vivo investigation of the GSH regeneration rate of intact erythrocytes demonstrated clearly that the overall activity of the glutathione oxidation-reduction pathway is not impaired in $\mathrm{Pb}$ and $\mathrm{Cd}$-exposed workers with significantly increased $\mathrm{Pb}-\mathrm{B}$ and $\mathrm{Cd}-\mathrm{B}$, since their initial GSH regeneration rate (first 15 minutes) was identical with that of the control group. Results of similar in vitro experiments in which control whole blood was incubated beforehand with $\mathrm{Pb}^{2+}$ or $\mathrm{Cd}^{2+}$, or both, reinforce this conclusion.

Since increased $\mathrm{Cd}-\mathrm{B}$ and $\mathrm{Pb}-\mathrm{B}$ do not influence the glutathione reductase system of erythrocytes, and since endogenous erythrocyte GSH is not correlated with Cd-B, the moderate decrease in endogenous erythrocyte GSH found in Pb-exposed workers might result from a $\mathrm{Pb}$-induced impairment of the erythrocyte mechanism for glutathione synthesis.

Of the heavy metals, cadmium, mercury, and lead, commonly recognized as toxic contaminants of our environment, only lead inhibits in vivo the human erythrocytic enzyme $\delta$-aminolevulinate dehydratase (ALAD, 5-aminolevulinate hydro-lyase; EC 4.2.1.24) specifically (Lauwerys and Buchet, 1973; Lauwerys,
Buchet, and Roels, 1973). This enzyme appears in vivo and in vitro to be extremely sensitive to the effect of inorganic lead $(\mathrm{Pb})$, and its activity closely and inversely correlates with the concentration of lead in blood ( $\mathrm{Pb}-\mathrm{B})$, even within the 'normal $\mathrm{Pb}-\mathrm{B}$ range', that is $0.7-1.9 \mu \mathrm{mol} / 1(15-40 \mu \mathrm{g} / 100 \mathrm{ml}$ ) (Hernberg 
and Nikkanen, 1972). A decreased activity of ALAD in mature erythrocytes of peripheral blood is considered to be a very early biological sign of exposure to lead (Hernberg et al., 1972) and under the usual environmental and occupational conditions $(\mathrm{Pb}-\mathrm{B}<5.8 \mu \mathrm{mol} / \mathrm{l}(120 \mu \mathrm{g} / 100 \mathrm{ml}))$ the activity as measured by test tube assay is a true reflection of the ALAD activity in vivo (Roels, Buchet, and Lauwerys, 1974). Although depressed ALAD activity in circulating erythrocytes can hardly have any significance for man's health, obviously it indicates indirectly a concomitant impairment of this enzyme by lead in haem-synthesizing tissues (Gibson and Goldberg, 1970; Millar et al., 1970; Kao and Forbes, 1973; Secchi, Erba, and Cambiaghi, 1974). In the concentration range $1 \cdot 2-4 \cdot 8 \mu \mathrm{mol} / 1 \quad(25-100 \mu \mathrm{g}$ $\mathrm{Pb} / 100 \mathrm{ml}$ blood), lead primarily exerts a noncompetitive inhibition of ALAD as shown for human (Granick et al., 1973) and bovine (Hapke and Prigge, 1973) erythrocyte ALAD; similar inhibition properties of $\mathrm{Pb}^{2+}$ were shown with purified beefliver ALAD (Wilson, Burger, and Dowdle, 1972). In addition, results of in vitro experiments with purified ALAD from different species strongly suggest that $\mathrm{Pb}$-ions probably affect this enzyme by inactivating its essential sulphydryl groups (Granick and Mauzerall, 1958; de Barreiro, 1967; Tomio, Tuzman, and Grinstein, 1968; Gibson and Goldberg, 1970; Granick et al. 1973).

The reversal of the ALAD deficit in Pb-poisoned erythrocytes of whole blood by preactivating the incubation mixture with thiol compounds has been demonstrated in vitro, for example, with reduced glutathione (GSH) (Lichtman and Feldman, 1963; Basecqz, Lauwerys, and Buchet, 1971; Hapke and Prigge, 1973), with cysteine (Heilmeyer, 1966), or with dithiotreitol (Granick et al., 1973). Similar observations were reported for rabbit liver ALAD after acute experimental lead-poisoning of the animals (de Barreiro, 1969). In vivo administration of GSH to workers with lead-intoxication improved the decreased erythrocyte ALAD activity to some extent (Nakao, Wada, and Yano, 1968). Several authors hypothesize that the endogenous concentration of GSH in erythrocytes or free -SH groups in liver cells play a regulating role in the activity of ALAD (de Barreiro, 1969; Moore et al., 1971 ; Granick et al., 1973).

The endogenous GSH concentration in erythrocytes is known to decrease moderately but significantly in workers intoxicated by lead (Shiraishi, 1952; Jonderko, 1961; Rubino et al., 1963; Bonsignore et al., 1967; Vasiliu, Stavri, and Freund, 1969; Batolska and Marinova, 1970). Its reduction occurs also in rabbits experimentally poisoned with lead (Nagai, Huse, and Saikawa, 1956; Jonderko and Sroczyński, 1963; Vergnano, Cartasegna, and Bonsignore, 1967). The biological significance of the high intracellular GSH concentration (2-2.5 mmoles/ litre packed erythrocytes $=0.4$ to $0.5 \mathrm{~mole} / \mathrm{mole}$ haemoglobin) for the normal function and structure of mature erythrocytes has been greatly clarified by the discovery of persons with a hereditary defect in the enzyme systems (glucose-6-phosphate dehydrogenase (G-6-PD) and glutathione synthetase) involved in the maintenance of the original high GSH level (Beutler, Robson, and Buttenwieser, 1957; Prins and Loos, 1969). Deficiency in one enzyme system, for example G-6-PD, can cause hypersusceptibility to occupational (Granzoni and Rhomberg, 1965; Steiger, 1968; Saita and Lussana, 1971) or environmental (McIntire and Angle, 1972) leadhazards.

However, the relationship between ALAD activity of lead-poisoned erythrocytes and their level of endogenous GSH has been interpreted by several authors in different ways: $(a)$ if a control mechanism for ALAD involving GSH exists, it might have been affected in intoxication with lead (de Barreiro, 1969); (b) the lead-induced loss of ALAD activity should scarcely be influenced by the endogenous GSH concentration (Granick et al., 1973); or (c) lead should not act directly on GSH, and the inhibition of ALAD would not be due to reduced levels of GSH (Cartasegna, Vergnano, and Ardoino, 1967; Vergnano et al., 1967). Concerning the effects of lead on the activity of erythrocyte G-6-PD (measured in haemolysates) conflicting results have been reported on occupationally lead-intoxicated workers (Rubino et al., 1963; Molé et al., 1965) and on experimentally lead-poisoned animals (Molé et al., 1965; Erich and Waller, 1967; Rogers et al., 1971).

Little is known about the interference of cadmium (Cd) with the in vivo activity of erthrocyte enzymes, but it is interesting to notice that the activities of both glutathione reductase and ALAD are affected in vitro by low $\mathrm{Cd}^{2+}$ concentrations. Indeed, purified human erythrocyte glutathione reductase (active form) which possesses sulphydryl group(s) in its active centre is inhibited by $50 \%$ in the presence of $1 \mu \mathrm{mol}$ $\mathrm{Cd}^{2+} /$ litre (Icèn, 1967). A low concentration of $\mathrm{Cd}^{2+}$ $(0.1 \mathrm{mmol} / \mathrm{litre})$ also inhibits at low substrate concentrations $(<1 \mathrm{mmol} / \mathrm{litre})$ purified beef-liver ALAD (Wilson et al., 1972). Human erythrocyte ALAD in normal whole blood appears to be in-

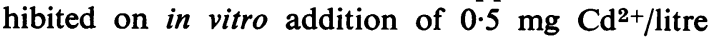
(Abdulla and Haeger-Aronsen, 1973).

Challenged by some of these conflicting data in the literature and the opposite hypothesis derived from them, we investigated during an epidemiological survey among workers exposed to lead and cadmium dust the interrelationships between three biological parameters, the concentration of $\mathrm{Pb}$ and $\mathrm{Cd}$ in blood, the activity of erythrocyte ALAD, and the endogenous GSH level of erythrocytes. Furthermore, in vivo and in vitro experiments were carried out with 
intact washed erythrocytes to evaluate the influence of increased blood lead and/or cadmium concentrations on the multi-enzyme system involved in the regeneration of endogenous GSH after its intracellular oxidation with methyl phenylazoformate (Kosower, Song, and Kosower, 1969a). Indeed, if cadmium or lead or both should significantly influence one or more enzymes involved in GSH regeneration, it would be reflected by the overall GSH regeneration rate of intact erythrocytes. In connexion with these in vivo and in vitro experiments we studied the distribution of $\mathrm{Pb}$ and $\mathrm{Cd}$ in whole blood of workers exposed to both metals and in control whole blood to which $\mathrm{Pb}^{2+}$ and/or $\mathrm{Cd}^{2+}$ were added in vitro. Finally, two methods, a chemical isolation (Beutler, Duron, and Kelly, 1963) and an enzymatic assay (Tietze, 1969), for determining glutathione in erythrocytes were compared.

\section{Materials and methods}

The ALAD activity of erythrocytes, the cadmium (Cd-B) and lead $(\mathrm{Pb}-\mathrm{B})$ concentration in whole blood, the content of reduced glutathione (GSH) in erythrocytes, and the regeneration rate of GSH by intact erythrocytes were measured during an epidemiological survey of 84 men employed in a Belgian cadmium and lead producing plant that differs from that mentioned in our previous paper (Lauwerys et al., 1973). A control group of 26 students and laboratory staff (including five women) was also examined. About $20 \mathrm{ml}$ of blood was obtained by venepuncture, immediately heparinized in capped polyethylene tubes, and kept at $4^{\circ} \mathrm{C}$ in a portable refrigerator.

Respirable dusts (aerodynamic diameter $<5 \mu$ ) were collected at different work places with the use of a gravimetric dust sampler (Casella, London, type 113A). The respirable $\mathrm{Cd}$ and $\mathrm{Pb}$ concentrations were measured by atomic absorption spectrophotometry; they ranged from 7.5 to 65 and from 3 to $26 \mu \mathrm{g} / \mathrm{m}^{3}$ respectively.

ALAD activity in whole blood was always measured 24 hours after blood withdrawal according to our method described previously (Lauwerys et al., 1973). The activity, corrected for the blood haematocrit, is expressed in units of absorbance for $2 \mathrm{~cm}$ light path:

$\left(A_{\text {analysis }}-A_{\text {blank }}\right) \times 10 /$ hour $/ \mathrm{ml}$ erythrocytes.

$\mathrm{Cd}-\mathrm{B}$ and $\mathrm{Pb}-\mathrm{B}$ were determined by the ion exchangeatomic absorption spectrophotometric method of Vens and Lauwerys (1972) and are expressed in nanomoles per litre (micrograms per $100 \mathrm{ml}$ ) and micromoles per litre (micrograms per $100 \mathrm{ml}$ ) of whole blood respectively. In some cases where the metal concentrations were very low, that is, in $\mathrm{Pb}$ and $\mathrm{Cd}$ uptake and distribution experiments, the $\mathrm{Pb}$ and $\mathrm{Cd}$ containing fractions of the eluate were extracted with ammonium pyrrolidine dithiocarbamate and 4-methyl-2-pentanone to concentrate the metals before the spectrophotometric reading.

Regeneration of GSH by intact erythrocytes was studied using a slight modification of the method of Kosower et al. (1969a). After centrifugation and removal of plasma and buffy coat, the erythrocytes from at least $6 \mathrm{ml}$ whole blood were washed twice with ice-cold 0.15 M
$\mathrm{NaCl}$ and their packed volume was adjusted with ice-cold $0.15 \mathrm{M} \mathrm{NaCl}$ in order to obtain an 80 to $90 \%$ erythrocyte suspension. Portions of $0.5 \mu \mathrm{l}$ of methyl phenyldiazenecarboxylate (azoester, methyl phenylazoformate) (Calbiochem, Los Angeles) were delivered into small test tubes $(5 \mathrm{ml})$ with a Hamilton syringe (Hamilton Co., Whittier, Calif., USA). A few seconds before the addition of the erythrocytes, the azoester was suspended in $0.3 \mathrm{ml}$ of ice-cold isotonic buffer $\left(\mathrm{NaCl} 0.133 \mathrm{M}, \mathrm{Na}_{2} \mathrm{HPO}_{4}\right.$ $0.01 \mathrm{M}$, glucose $0.01 \mathrm{M}$ ) used as the incubation medium, then $0.3 \mathrm{ml}$ erythrocyte suspension was added with a constriction pipette and mixed gently. This mixture was kept in an ice-bath for 10 minutes to allow the intracellular oxidation of GSH by azoester, and then incubated at $37^{\circ} \mathrm{C}$. Aliquots of $0.1 \mathrm{ml}$ were removed from this mixture to determine the level of GSH at zero time and after 15, 30, and 60 minutes of incubation. Preliminary experiments have indicated that an almost complete oxidation, and similar and satisfactory (more than $70 \%$ ) yields of regenerated GSH were obtained with oxidation periods (in an ice-bath) of $3,6,10,20,30$, and 60 minutes. For practical reasons an oxidation period of 10 minutes was chosen.

In vitro experiments were carried out with intact erythrocytes in order to evaluate the effect of added heavy metal ions $\left(\mathrm{Cd}^{2+}, \mathrm{Pb}^{2+}\right)$ on the GSH regeneration rate after intracellular oxidation of GSH with azoester. Portions of $7 \mathrm{ml}$ heparinized normal whole blood ( $\mathrm{Pb}-\mathrm{B}$ $0.94 \mu \mathrm{mol} / 1(19.4 \mu \mathrm{g} / 100 \mathrm{ml})$ and Cd-B $22.3 \mathrm{nmol} / 1$ $(0.25 \mu \mathrm{g} / 100 \mathrm{ml}))$ were transferred in polyethylene tubes and mixed gently with small volumes (50 to $200 \mu \mathrm{l})$ of aqueous solutions of $\mathrm{PbCl}_{2}(106 \mu \mathrm{mol} / \mathrm{l})$ and/or $\mathrm{CdCl}_{2}$ (7.2 $\mu \mathrm{mol} / \mathrm{l})$ added beforehand. $\mathrm{PbCl}_{2}$ and $\mathrm{CdCl}_{2}$ were dissolved in $0.15 \mathrm{M} \mathrm{NaCl}$.

$\mathrm{Pb}$-B levels up to $6.8 \mu \mathrm{mol} / \mathrm{l}(140 \cdot 7 \mu \mathrm{g} / 100 \mathrm{ml})$ (with a constant Cd-B level of $22 \cdot 3 \mathrm{nmol} / 1(0 \cdot 25 \mu \mathrm{g} / 100 \mathrm{ml}))$ and Cd-B levels up to $371 \mathrm{nmol} / 1(4 \cdot 17 \mu \mathrm{g} / 100 \mathrm{ml})$ (with a constant $\mathrm{Pb}$-B level of $0.94 \mu \mathrm{mol} / 1(19.4 \mu \mathrm{g} / 100 \mathrm{ml})$ ) were prepared. In two other samples the concentration of both metals was increased. The tubes were kept at $37^{\circ} \mathrm{C}$ for one hour and at $4^{\circ} \mathrm{C}$ overnight. The GSH level of the washed erythrocytes and their GSH regeneration rate were then assayed.

Similar blood samples were prepared to estimate the uptake and distribution of lead and cadmium added in vitro. The distribution of lead in normal whole blood charged in vitro with $\mathrm{Pb}^{2+}(\mathrm{Pb}-\mathrm{B}$ increased from 0.94 to $2.95 \mu \mathrm{mol} / 1(19 \cdot 4$ to $61 \mu \mathrm{g} / 100 \mathrm{ml}))$ was also compared with that in whole blood from a worker occupationally exposed to $\mathrm{Pb}(\mathrm{Pb}-\mathrm{B}$ of $3 \cdot 3 \mu \mathrm{mol} / \mathrm{l}(68 \mu \mathrm{g} / 100 \mathrm{ml})$ ). Plasma was separated from the erythrocytes by centrifugation of the blood samples (about $10 \mathrm{ml}$ ) at room temperature in a Sorvall GLC-1 (10 min, $2600 \mathrm{rev} / \mathrm{min})$ and the erythrocytes were washed twice with ice-cold $0.15 \mathrm{M} \mathrm{NaCl}$. The erythrocytes were haemolysed by adding $100 \mathrm{ml}$ ice-cold deionized water, and the mixture was kept for 30 minutes at $-20^{\circ} \mathrm{C}$. The haemolysate was subsequently centrifuged in a Sorvall RC2-B at $0^{\circ} \mathrm{C}(20$ $\mathrm{min}, 20000 \mathrm{rev} / \mathrm{min}$, rotor SS-34); the supernatant cytosol was decanted and the pellet (erythrocyte ghosts) washed with portions of $30 \mathrm{ml}$ ice-cold deionized water until the supernatant became nearly colourless (four washings). The cytosol and the first wash were combined, while the three other subsequent washes were kept apart. Plasma, 
TABLE 1

Interrelationships between Different Biological Parameters in BloOd of Total Study Population ${ }^{1}$

\begin{tabular}{|c|c|c|c|c|}
\hline \multicolumn{3}{|c|}{ Partial correlation coefficients } & \multirow{2}{*}{$\mathbf{P}$} & \multirow{2}{*}{ Regression equation } \\
\hline Factors correlated & $\begin{array}{l}\text { Factor held } \\
\text { constant }\end{array}$ & $\mathbf{r}$ & & \\
\hline $\begin{array}{l}\log \text { ALAD } \log \text { Pt-B } \\
\log \text { ALAD } \log \text { Cd-B } \\
\text { GSH . log Pb-B } \\
\text { GSH } . \log \text { Cd-B } \\
\log \text { ALAD GSH } \\
\log \text { ALAD } \log \text { Pb-B }\end{array}$ & $\begin{array}{l}\log \mathrm{Cd}-\mathrm{B} \\
\log \mathrm{Pb}-\mathrm{B} \\
\log \mathrm{Cd}-\mathrm{B} \\
\log \mathrm{Pb}-\mathrm{B} \\
\log \mathrm{Pb}-\mathrm{B} \\
\text { GSH }\end{array}$ & $\begin{array}{l}-0.760 \\
-0.093 \\
-0.423 \\
-0.050 \\
+0.075 \\
-0.748\end{array}$ & $\begin{array}{l}<0.001 \\
>0.05 \\
<0.001 \\
>0.05 \\
>0.05 \\
<0.001\end{array}$ & $\begin{array}{l}\log \text { ALAD }=2.640-0.982(\log \mathrm{Pb}-\mathrm{B}) \\
\mathrm{GSH}=85.74-13.87(\log \mathrm{Pb}-\mathrm{B}) \\
\log \mathrm{ALAD}=2.639-0.983(\log \mathrm{Pb}-\mathrm{B})\end{array}$ \\
\hline
\end{tabular}

${ }^{1}$ The total study population consists of 110 subjects, 26 controls and 84 workers.

combined saline washes, erythrocyte ghosts, cytosol, and the washes of the erythrocyte ghosts were analysed for lead and cadmium.

GSH was determined according to the metaphosphoric acid method of Beutler et al. (1963) using ice-cold $2.7 \mathrm{mM}$ ethylenediaminetetraacetic acid, disodium salt (EDTA), for haemolysis of the erythrocytes. The GSH content of washed erythrocytes not treated with azoester was determined with $0.3 \mathrm{ml}$ erythrocyte suspension added to $5.7 \mathrm{ml}$ EDTA solution, and that of treated erythrocytes with $0.1 \mathrm{ml}$ added to $0.9 \mathrm{ml}$ EDTA solution. The haemolysates were kept in an ice-bath until addition of the protein-precipitating reagent $\left(\mathrm{HPO}_{3}-\mathrm{NaCl}-\mathrm{EDTA}\right)$. The coagulated proteins were removed by centrifugation at room temperature (Sorvall GLC-1, $10 \mathrm{~min}, 2600 \mathrm{rev} /$ $\mathrm{min}$ ) and then $4 \mathrm{ml}$ of $0.3 \mathrm{M} \mathrm{Na}_{2} \mathrm{HPO}_{4}$ were added to $1 \mathrm{ml}$ of the supernatant. Fifteen minutes later $0.5 \mathrm{ml}$ of a

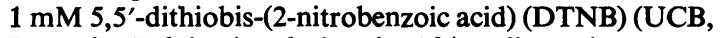
Brussels, Belgium) solution in $1 \%$ sodium citrate was added; 2 minutes later the absorbance was measured with a Zeiss PMQ2 spectrophotometer at $412 \mathrm{~nm}$ in a $2 \mathrm{~cm}$ cuvette. The amount of GSH was calculated using $\epsilon_{M}=$ $136001 \mathrm{~mol}^{-1} \mathrm{~cm}^{-1}$ and is expressed in milligrams per $100 \mathrm{ml}$ of packed erythrocytes.

The total glutathione content (reduced + oxidized glutathione) in washed erythrocytes and whole blood was also measured according to the glutathione reductase method of Tietze (1969) by means of a single beam spectrophotometer equipped with a thermostated cuvette compartment. Reduced glutathione (Sigma Chemical Company, St-Louis, Mo., USA) was used for the standard calibration line (50 to $200 \mathrm{ng}$ GSH) and a blank was run several times to check the reagents (NADPH and yeast glutathione reductase; Boehringer, Mannheim, West Germany). The reactions were performed at $37^{\circ} \mathrm{C}$ using potassium phosphate as buffer salts and $1 \mathrm{mM}$ NADPH as the final concentration.

\section{Results}

\section{In vivo experiments}

Total study population The mean value of lead and cadmium in whole blood of the total study population was $1.4 \mu \mathrm{mol} / 1$ and $89 \mathrm{nmol} / 1(29.8$ and 1.0 $\mu \mathrm{g} / 100 \mathrm{ml}$ ) respectively; $\mathrm{Pb}-\mathrm{B}$ ranged from 0.2 to 3.5 $\mu \mathrm{mol} / \mathrm{l}(4.5$ to $72.7 \mu \mathrm{g} / 100 \mathrm{ml})$ and Cd-B from 4.45 to $457.5 \mathrm{nmol} / 1(0.05$ to $5.14 \mu \mathrm{g} / 100 \mathrm{ml})$. Both parameters were not normally distributed (see below). The mean level \pm standard deviation (SD) of reduced glutathione in washed erythrocytes was $66.2 \pm 7.43$ per $100 \mathrm{ml}$ erythrocytes.

In order to check whether the measured biological parameters were normally distributed in the total study population we applied the curve fitting $\chi^{2}$ method to the obtained values. Only those of GSH showed a normal distribution, but the values of $\mathrm{Pb}-\mathrm{B}, \mathrm{Cd}-\mathrm{B}$, and ALAD needed a logarithmic transformation to make their distribution normal. Table 1 shows the interrelationships between the biological parameters measured in the total population. In view of the significant correlation coefficient between $\log \mathrm{Pb}-\mathrm{B}$ and $\log \mathrm{Cd}-\mathrm{B}(\mathrm{r}=0.404)$ we

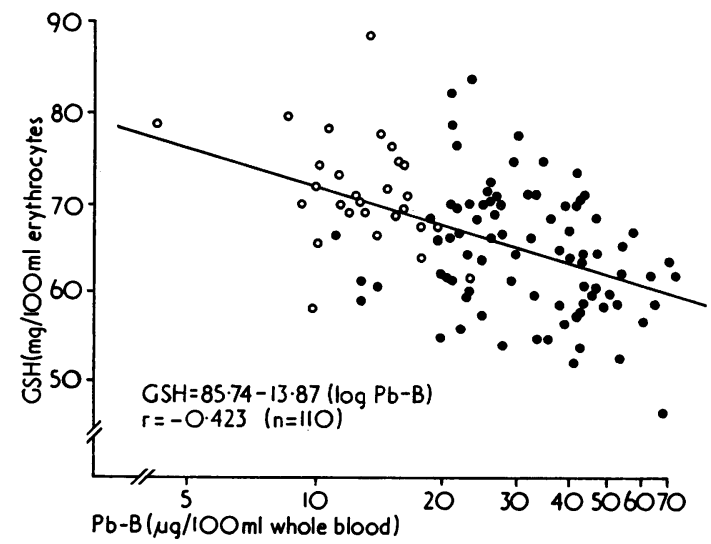

FIG. 1. Relationship in total study population $(n=110)$ between the level of reduced glutathione (GSH) in erythrocytes and lead in blood (log scale) standardized for a given level of cadmium in blood, $\log \mathrm{Cd}-\mathrm{B}=-0.2287$ (mean value of $\log \mathrm{Cd}-\mathrm{B}$ in the total study population); (O) 26 control subjects, (O) 84 workers from lead and cadmium producing plant. Conversion: Traditional to $S I$ units-lead: $1 \mu \mathrm{g} / 100 \mathrm{ml} \approx 0.0483 \mu \mathrm{mol} / 1$. 
had to compute partial correlation coefficients between these two parameters and GSH or log ALAD in order to distinguish unambiguously the effect of both heavy metals. Log ALAD is highly inversely correlated with $\log \mathrm{Pb}-\mathrm{B}(\mathrm{r}=-0.760 ; \mathrm{P}<0.001)$ but not with $\log \mathrm{Cd}-\mathrm{B}$, confirming our previous results (Lauwerys et al., 1973). The partial correlations between GSH and $\log \mathrm{Pb}-\mathrm{B}$ (standardized for $\log$ Cd-B) and between GSH and log Cd-B (standardized for $\log \mathrm{Pb}-\mathrm{B}$ ) demonstrated a significant negative correlation between GSH and $\log \mathrm{Pb}-\mathrm{B}$ $(r=-0.423 ; P<0.001$ ) (Fig. 1) but no relationship between GSH and $\log$ Cd-B (Fig. 2).

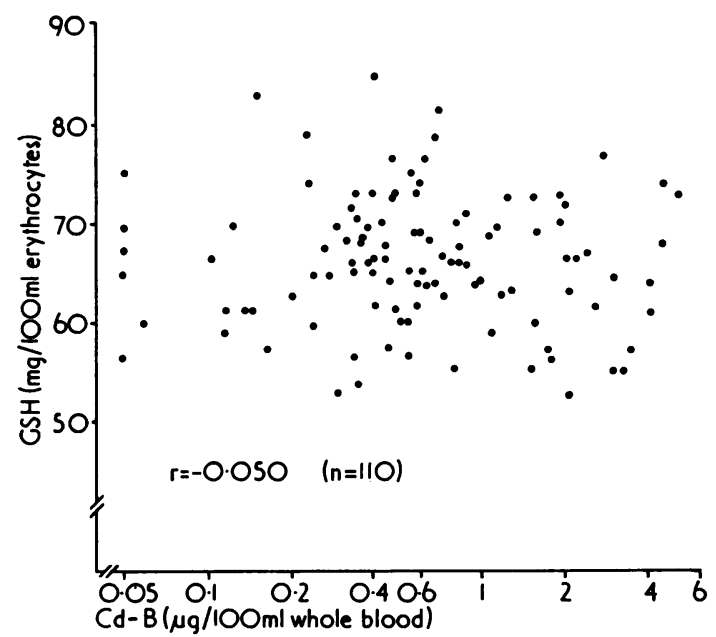

FIG. 2. Relationship in total study population $(n=110)$ between the level of reduced glutathione (GSH) in erythrocytes and blood cadmium (log scale) standardized for a given level of lead in blood, $\log \mathrm{Pb}-\mathrm{B}=1.4104$ (mean value of $\log \mathrm{Pb}-\mathrm{B}$ in the total study population); (O) 26 control subjects, (O) 84 workers from lead and cadmium producing plant. Conversion: Traditional to $S I$ units-cadmium: $1 \mu \mathrm{g} / 100 \mathrm{ml} \approx 89.0 \mathrm{nmol} / 1$.
The significant correlation coefficient found between $\log$ ALAD and GSH $(r=0.414 ; P<0.001)$ could be fortuitous, since both parameters are significantly correlated with $\log \mathrm{Pb}-\mathrm{B}$. Therefore the partial correlation coefficients between log ALAD and GSH (standardized for $\log \mathrm{Pb}-\mathrm{B}$ ) and between $\log$ ALAD and $\log \mathrm{Pb}-\mathrm{B}$ (standardized for GSH) were calculated (Table 1). The apparently good relationship between $\log$ ALAD and GSH disappeared completely by holding $\log \mathrm{Pb}-\mathrm{B}$ constant $(r=0.075 ; P>0.05)$ but $\log$ ALAD remained highly inversely correlated with $\log \mathrm{Pb}-\mathrm{B}$ when standardized for GSH concentration $(r=-0.748$; $P<0.001$ ).

Subgroups Besides the control group $(n=26)$ the workers of the cadmium and lead producing plant can be classified into two subgroups according to their $\mathrm{Pb}-\mathrm{B}$, that is, subgroup $\mathrm{I}(\mathrm{n}=58$; upper individual limit of $\mathrm{Pb}-\mathrm{B} \leqslant 2 \cdot 1 \mu \mathrm{mol} / 1(42 \cdot 5 \mu \mathrm{g} / 100$ $\mathrm{ml})$; group average $\mathrm{Pb}-\mathrm{B}=1 \cdot 3 \mu \mathrm{mol} / 1(27 \cdot 1 \mu \mathrm{g} / 100$ $\mathrm{ml})$ ) and subgroup II $(\mathrm{n}=26 ; 2.1<\mathrm{Pb}-\mathrm{B} \leqslant 3.5$ $\mu \mathrm{mol} / 1 \quad(42.5<\mathrm{Pb}-\mathrm{B} \leqslant 72.7 \mu \mathrm{g} / 100 \mathrm{ml})$; group average $\mathrm{Pb}-\mathrm{B}=2.5 \mu \mathrm{mol} / \mathrm{l}(52.2 \mu \mathrm{g} / 100 \mathrm{ml}))$. Both subgroups are age-matched. $\mathrm{A} \mathrm{Pb}-\mathrm{B}$ of $2 \cdot 1 \mu \mathrm{mol} / 1$ $(42.5 \mu \mathrm{g} / 100 \mathrm{ml})$ as criterion of classification looks reasonable, since a $\mathrm{Pb}-\mathrm{B}$ of $1 \cdot 9-2 \cdot 2 \mu \mathrm{mol} / 1$ (40-45 $\mu \mathrm{g} / 100 \mathrm{ml})$ can be considered a critical threshold value (Zielhuis, 1973; Lauwerys et al., 1974). According to Zielhuis' (1973) proposal, subgroup I can be considered a population representative of exposure to environmental conditions (public health) whereas subgroup II represents occupational exposure (occupational health).

Table 2 gives the mean values of the biological parameters measured in the control group and the two subgroups of workers. By comparison with the control group $(\mathrm{Pb}-\mathrm{B}=0.6 \mu \mathrm{mol} / \mathrm{l}(13.3 \mu \mathrm{g} / 100 \mathrm{ml}))$ subgroups I and II show a statistically significant decrease of haematocrit, of ALAD activity, and of

TABLE 2

Biological Parameters of Different Subgroups in Study Population $($ mean \pm SEM)

\begin{tabular}{|c|c|c|c|c|c|c|c|}
\hline Subgroup & $\begin{array}{c}\text { No. of } \\
\text { subjects }\end{array}$ & $\begin{array}{c}\text { Age } \\
\text { (years) }\end{array}$ & $\begin{array}{c}\text { Haematocrit }^{1} \\
(\%)\end{array}$ & $A L A D^{2}$ & $\begin{array}{c}P b-B \\
(\mu \mathrm{mol} / l)\end{array}$ & $\begin{array}{c}C d-B \\
(n m o l / l)\end{array}$ & $\mathrm{GSH}^{3}$ \\
\hline $\begin{array}{c}\text { Controls } \\
\text { I } \\
\text { II }\end{array}$ & $\begin{array}{l}26 \\
58 \\
26\end{array}$ & $\begin{array}{l}25 \cdot 9 \pm 1 \cdot 0 \\
40 \cdot 7 \pm 1 \cdot 3^{*} \\
43 \cdot 2 \pm 2 \cdot 0^{*}\end{array}$ & $\begin{array}{l}45.3 \pm 0.4 \\
43.6 \pm 0.3^{*} \\
43.6 \pm 0.5^{*}\end{array}$ & $\begin{array}{c}43.8 \pm 2.1 \\
19.5 \pm 1.2^{*} \\
9.0 \pm 0.8 \dagger\end{array}$ & $\begin{array}{l}0.64 \pm 0.03 \\
1.31 \pm 0.05^{*} \\
2.52 \pm 0.08 \dagger\end{array}$ & $\begin{array}{c}40.9 \pm 4.5 \\
75.7 \pm 11 \cdot 6 \\
165 \cdot 5 \pm 24.0 \dagger\end{array}$ & $\begin{array}{l}71.8 \pm 1.2 \\
66.0 \pm 0.9 * \\
60.9 \pm 1.0 \dagger\end{array}$ \\
\hline
\end{tabular}

SEM = standard error of the mean

${ }^{1}$ The controls include five women who were not taken into account for the haematocrit

${ }^{2}$ ALAD activity expressed in absorbance units $\times 10 /$ hour $/ \mathrm{ml}$ erythrocytes for $2 \mathrm{~cm}$ light path

${ }^{3} \mathrm{GSH}$ : glutathione content of erythrocytes expressed in $\mathrm{mg}$ per $100 \mathrm{ml}$ erythrocytes

* Means significantly different from the control value $(P<0.05)$

† Means significantly different from subgroup I and the control value $(P<0.05)$

Conversion: SI to Traditional units-lead $1 \mu \mathrm{mol} / 1 \approx 20.7 \mu \mathrm{g} / 100 \mathrm{ml}$

$$
\longrightarrow \text { cadmium } 1 \mathrm{nmol} / 1 \approx 0.0112 \mu \mathrm{g} / 100 \mathrm{ml}
$$


GSH content of the erythrocytes, and the average $\mathrm{Pb}-\mathrm{B}$ level is raised to 1.3 and $2.5 \mu \mathrm{mol} / 1$ (27.1 and $52.2 \mu \mathrm{g} / 100 \mathrm{ml}$ ) respectively. Moreover, the mean values of ALAD activity and GSH content of subgroup II are statistically significantly lower than those of subgroup I. The haematocrit in both subgroups of workers is the same and only the Cd-B mean value of subgroup II differs significantly from that of the two other groups.

The investigation of the GSH regeneration rate in intact erythrocytes after intracellular oxidation of the endogenous GSH by azoester is summarized in Figure 3. The mean level of endogenous GSH

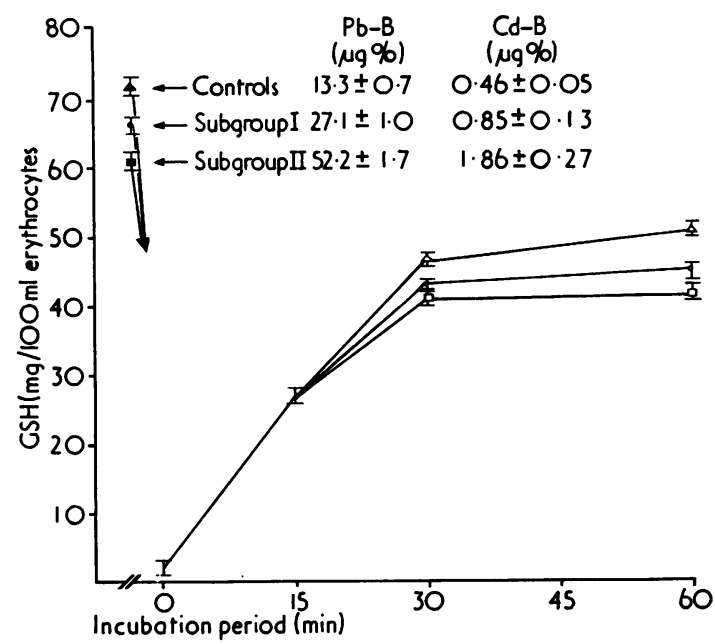

FIG. 3. Regeneration rate of GSH by intact erythrocytes from two groups of workers employed in a lead and cadmium producing plant; $(O)$ subgroup I (58 subjects) and ( $\square$ ) subgroup II (26 subjects), and from a control group of 26 subjects $(\triangle)$ without occupational exposure. Intact erythrocytes were preincubated $\left(10 \mathrm{~min}\right.$ at $\left.0^{\circ} \mathrm{C}\right)$ with the incubation medium containing methyl phenylazoformate, and then incubated at $37^{\circ} \mathrm{C}$ for $60 \mathrm{~min}$. Aliquots were removed after $0,15,30$, and 60 minutes of incubation to determine the amount of regenerated GSH. The symbols $(\Delta, \square, O)$ represent the endogenous erythrocyte GSH amount of the respective groups before the addition of methyl phenylazoformate; the concentrations of lead and cadmium in blood (Pb-B and Cd-B in $\mu \mathrm{g} \mathrm{\%}$ ) are also given for each group. Mean values \pm standard error of the mean are shown. Conversion: Traditional to SI units-lead $1 \mu \mathrm{g} / 100 \mathrm{ml} \approx 0.0483 \mu \mathrm{mol} / 1$ : cadmium $1 \mu \mathrm{g} / 100 \mathrm{ml} \approx 89.0 \mathrm{nmol} / \mathrm{l}$.

amounted to $71 \cdot 8,66 \cdot 0$, and $60 \cdot 9 \mathrm{mg} / 100 \mathrm{ml}$ erythrocytes (see Table 2 ) respectively for the control group, subgroup I, and subgroup II of the workers. The azoester oxidized GSH efficiently, since the amount of GSH at zero time never exceeded $5 \%$ of the endogenous amount found before azoester treatment. After 15 minutes of incubation at $37^{\circ} \mathrm{C}$ the GSH levels of the three groups rise tc almost the same values (mean $\pm \mathrm{SD}$ ), that is, $27.3 \pm 3.5 \mathrm{mg}$ for the control group, and $26 \cdot 4 \pm 4 \cdot 1$, and $26 \cdot 6 \pm 3 \cdot 1$ $\mathrm{mg}$ for subgroups I and II respectively. This indicates that the initial rate of GSH regeneration of the glutathione reductase system is similar for the three groups, whatever their content of $\mathrm{Pb}$ and $\mathrm{Cd}$ in blood. The GSH levels increased further in the next 15 minutes and then reached almost a plateau during the next 30 minutes. The statistically significant differences between the GSH levels after 60 minutes of regeneration reflect those observed before azoester treatment. Approximately $70 \%$ of the original GSH level was regenerated, which corresponds to (mean \pm SD) $51.3 \pm 5.7 \mathrm{mg}$ for the control group, and to $45.1 \pm 6.2$ and $42.2 \pm 4.9 \mathrm{mg}$ for subgroups I and II respectively. In view of the molar ratio azoester: GSH $=5$, a $70 \%$ yield of regenerated GSH could be expected (see also Kosower et al. (1969b) and Yawata and Tanaka (1973)).

\section{In vitro experiments}

Effect of $\mathrm{Pb}^{2+}$ and $\mathrm{Cd}^{2+}$ added in vitro on GSH regeneration Table 3 shows the results obtained for GSH regeneration by intact erythrocytes after treatment with azoester. The erythrocytes were isolated from control whole blood of which the $\mathrm{Pb}-\mathrm{B}$ and/or $\mathrm{Cd}-\mathrm{B}$ was increased by direct addition of small volumes of a $\mathrm{PbCl}_{2}$ and/or $\mathrm{CdCl}_{2}$ solution. The added amounts of $\mathrm{Pb}^{2+}$ and/or $\mathrm{Cd}^{2+}$ were such that the new $\mathrm{Pb}-\mathrm{B}$ and $\mathrm{Cd}-\mathrm{B}$ levels remained comparable with levels currently observed in the general population and in workers occupationally exposed to these heavy metals. The GSH levels of the treated samples before azoester addition and those after various regeneration periods following azoester addition did not differ significantly from the corresponding GSH levels of the control sample (no heavy metal added). It can therefore be concluded that this concentration range of in vitro added $\mathrm{Pb}^{2+}$ and $\mathrm{Cd}^{2+}$ has no effect on the glutathione reductase system of intact erythrocytes, and this result reinforces that obtained in vivo.

Uptake and distribution of $\mathrm{Pb}^{2+}$ and $\mathrm{Cd}^{2+}$ added in vitro The conclusion drawn from the preceding results can be valid only if under the actual experimental conditions the erythrocytes took up in vitro substantial amounts of $\mathrm{Pb}$ and $\mathrm{Cd}$. When increasing amounts of $\mathrm{Pb}^{2+}$ and $\mathrm{Cd}^{2+}$ were added in vitro to control whole blood (Pb-B of $0.9 \mu \mathrm{mol} / 1$ (19.4 $\mu \mathrm{g} / 100 \mathrm{ml})$ and $\mathrm{Cd}-\mathrm{B}$ of $22 \cdot 3 \mathrm{nmol} / \mathrm{l}(0 \cdot 25 \mu \mathrm{g} / 100 \mathrm{ml}))$ to increase $\mathrm{Pb}-\mathrm{B}$ and $\mathrm{Cd}-\mathrm{B}$ up to a level of 3.5 $\mu \mathrm{mol} / 1$ and $194 \mathrm{nmol} / 1(71.8$ and $2.18 \mu \mathrm{g} / 100 \mathrm{ml})$ respectively, we observed that uptake and distribution of added $\mathrm{Pb}$ differed remarkably from that of added $\mathrm{Cd}$. At least $80 \%$ of the added amount of $\mathrm{Pb}$ 
TABLE 3

Regeneration of GSH by ERythrocytes after Addition of $\mathrm{Pb}^{2+}$ and/or $\mathrm{Cd}^{2+}$ To CONTROL WhOLE BLOOD in vitro

\begin{tabular}{|c|c|c|c|c|c|c|c|}
\hline \multirow{3}{*}{ Sample } & \multirow{3}{*}{$\begin{array}{c}P b-B \\
(\mu \mathrm{mol} / l)\end{array}$} & \multirow{3}{*}{$\begin{array}{c}C d-B \\
(n m o l / l)\end{array}$} & \multicolumn{5}{|c|}{ GSH $(\mathrm{mg} / 100 \mathrm{ml}$ erythrocytes $)$} \\
\hline & & & \multirow{2}{*}{$\begin{array}{c}\text { Before } \\
\text { addition of } \\
\text { azoester }\end{array}$} & \multicolumn{4}{|c|}{ Regeneration period (min) } \\
\hline & & & & 0 & 15 & 30 & 60 \\
\hline Control $^{1}$ & 0.94 & $22 \cdot 3$ & $66 \cdot 3 \pm 1 \cdot 4$ & $2 \cdot 7 \pm 0 \cdot 6$ & $36 \pm 2 \cdot 1$ & $51 \cdot 1 \pm 2 \cdot 4$ & $49 \cdot 5 \pm 2 \cdot 0$ \\
\hline $\mathrm{Pb}^{2+}$ added & $\begin{array}{l}1 \cdot 66 \\
2 \cdot 38 \\
3 \cdot 84 \\
6 \cdot 80\end{array}$ & $\begin{array}{l}22 \cdot 3 \\
22 \cdot 3 \\
22 \cdot 3 \\
22 \cdot 3\end{array}$ & $\begin{array}{l}67 \cdot 8 \\
66 \cdot 8 \\
68 \cdot 1 \\
66 \cdot 8\end{array}$ & $\begin{array}{l}0 \cdot 7 \\
2 \cdot 1 \\
3 \cdot 0 \\
3 \cdot 1\end{array}$ & $\begin{array}{l}36 \cdot 6 \\
37 \cdot 0 \\
36 \cdot 2 \\
33 \cdot 1\end{array}$ & $\begin{array}{l}50 \cdot 5 \\
50 \cdot 7 \\
53 \cdot 4 \\
51 \cdot 7\end{array}$ & $\begin{array}{l}49 \cdot 5 \\
50 \cdot 7 \\
51 \cdot 7 \\
49 \cdot 0\end{array}$ \\
\hline $\mathrm{Cd}^{2+}$ added & $\begin{array}{l}0.94 \\
0.94 \\
0.94\end{array}$ & $\begin{array}{r}71 \cdot 2 \\
170 \cdot 0 \\
371 \cdot 1\end{array}$ & $\begin{array}{l}64 \cdot 9 \\
68 \cdot 4 \\
67 \cdot 5\end{array}$ & $\begin{array}{l}2 \cdot 8 \\
2 \cdot 7 \\
2 \cdot 7\end{array}$ & $\begin{array}{l}39 \cdot 0 \\
34 \cdot 0 \\
35 \cdot 4\end{array}$ & $\begin{array}{l}53 \cdot 5 \\
51 \cdot 7 \\
49 \cdot 8\end{array}$ & $\begin{array}{l}48 \cdot 3 \\
48 \cdot 0 \\
49 \cdot 0\end{array}$ \\
\hline $\mathrm{Pb}^{2+}$ and $\mathrm{Cd}^{2+}$ added & $\begin{array}{l}1 \cdot 67 \\
3 \cdot 13\end{array}$ & $\begin{array}{r}72 \cdot 1 \\
170 \cdot 9\end{array}$ & $\begin{array}{l}66 \cdot 8 \\
65 \cdot 6\end{array}$ & $\begin{array}{l}3 \cdot 4 \\
2 \cdot 5\end{array}$ & $\begin{array}{l}36 \cdot 8 \\
34 \cdot 9\end{array}$ & $\begin{array}{l}46 \cdot 9 \\
49 \cdot 0\end{array}$ & $\begin{array}{l}47 \cdot 2 \\
47 \cdot 2\end{array}$ \\
\hline
\end{tabular}

${ }^{1}$ The GSH values for the control sample are mean \pm SD values from four determinations; all the others are single values Conversion: SI to Traditional units-lead $1 \mu \mathrm{mol} / 1 \approx 20.7 \mu \mathrm{g} / 100 \mathrm{ml}$ - cadmium $1 \mathrm{nmol} / 1 \approx 0.0112 \mu \mathrm{g} / 100 \mathrm{ml}$

was taken up by the erythrocytes, whereas about $75 \%$ of the added amount of $\mathrm{Cd}$ was found in the plasma and only 10 to $20 \%$ was taken up by the erythrocytes in vitro. Although the Cd level of the erythrocytes increased by three to four times, it never reached levels as high as those found in erythrocytes of persons occupationally exposed to this metal (for example, workers of subgroup II). On the contrary, approximately $90 \%$ of the total amount of lead was found to be associated with the erythrocytes-on average, $5 \%$ with the erythrocyte ghosts and $85 \%$ with the soluble erythrocyte constituents; the remainder was found partially in the plasma and partially in the combined saline washes. Similar results are obtained for in vivo distribution of lead in blood (Table 4).

In addition to these in vitro experiments the distribution study of $\mathrm{Pb}$ and $\mathrm{Cd}$ in blood from workers of subgroup II confirmed data in the literature, that in vivo both Cd (Carlson and Friberg, 1957; Nordberg, Piscator, and Nordberg, 1971) and $\mathrm{Pb}$ (Bruenger et al., 1973) are hardly detectable in plasma. Haemoglobin appeared to serve as binding protein for $\mathrm{Pb}$ (Barltrop and Smith, 1971; Bruenger

TABLE 4

Distribution of Pb in Whole Blood of a Pb-intoxicated Worker and in NORMAL WHOLE BLOOD WITH Pb ${ }^{2+}$ ADDED

\begin{tabular}{|c|c|c|}
\hline Amount of $\mathrm{Pb}$ & $\begin{array}{l}\text { Pb-intoxicated worker } \\
(P b-B 3 \cdot 28 \mu \mathrm{mol} / \mathrm{l})\end{array}$ & $\begin{array}{l}\text { Normal with } \mathrm{Pb}^{2+} \text { added } \\
(\mathrm{Pb}-\mathrm{B} 2.95 \mathrm{\mu mol} / \mathrm{l})\end{array}$ \\
\hline In original sample ${ }^{1}(\mu \mathrm{mol})$ & $0.0347 \mu \mathrm{mol}$ & 0.0311 \\
\hline $\begin{array}{l}\text { In the different fractions ( } \mu \mathrm{mol}) \\
\text { Plasma } \\
\text { Saline washes } \\
\text { Erythrocyte ghosts } \\
\text { Erythrocyte constituents }\end{array}$ & $\begin{array}{ll}0.0008 & (2.4 \%)^{2} \\
0.0006 & (1.8 \%) \\
0.0078 & (23.6 \%) \\
0.0237(72.2 \%)\end{array}$ & $\begin{array}{ll}0.0017 & (5.1 \%)^{2} \\
0.0011 & (3.3 \%) \\
0.0019 & (5.7 \%) \\
0.0292(85.9 \%)\end{array}$ \\
\hline Total recovered $(\mu \mathrm{mol})$ & 0.0329 & 0.0339 \\
\hline Recovery & $95 \%$ & $109 \%$ \\
\hline
\end{tabular}

${ }^{1}$ About $10 \mathrm{ml}$ blood was used for the fractionation

${ }^{2}$ Within parentheses are the percentages for the $\mathrm{Pb}$-amounts relative to the total amount of $\mathrm{Pb}$ recovered

Conversion: SI to Traditional units-lead $1 \mu \mathrm{mol} / 1 \approx 20.7 \mu \mathrm{g} / 100 \mathrm{ml}$ 
TABLE 5

COMPARISON OF BEUTLER'S AND TIETZE's METHOD FOR THE DETERMINATION OF GLUTATHIONE IN HUMAN ERYTHROCYTES

$(\text { mean } \pm \mathrm{SD})^{1}$

\begin{tabular}{c|c|c|c}
\hline \multirow{2}{*}{ Subject } & \multicolumn{2}{|c|}{$\begin{array}{c}\text { Washed erythrocytes } \\
\text { (mg GSH/100 ml erythrocytes })\end{array}$} & $\begin{array}{c}\text { Whole blood } \\
(\mu \mathrm{GSH} / \mathrm{ml})\end{array}$ \\
\cline { 2 - 3 } & Beutler's method & Tietze's method & Tietze's method \\
\hline TS & $89.5 \pm 0.8$ & $99 \cdot 2 \pm 7.7$ & $549 \pm 37$ \\
HR & $72.8 \pm 1.2$ & $87.7 \pm 9.9$ & $485 \pm 24$ \\
JPB & $71.5 \pm 1.0$ & $85.1 \pm 5 \cdot 7$ & $470 \pm 51$ \\
\hline
\end{tabular}

${ }^{1}$ Mean \pm SD for three determinations

et al., 1973) and Cd (Carlson and Friberg, 1957; Nordberg et al., 1971), but more than $60 \%$ of $\mathrm{Cd}$ seemed to be bound to erythrocyte metallothionein (Nordberg et al., 1971). It is therefore quite astonishing still to find in a recent publication that the utility of measuring $\mathrm{Cd}$ concentration in plasma as an index of exposure is stressed (Colucci et al., 1973).

Comparison of assays for the determination of erythrocyte glutathione

Two methods were compared, Beutler's and Tietze's. With the former, only chemically isolated GSH is measured spectrophotometrically; with the latter, the total content of glutathione (GSH + GSSG) is measured enzymatically with yeast glutathione reductase. Preliminary results showed that ergothionein, of which an appreciable amount is present in the erythrocytes, did not react with DTNB in the conditions in which erythrocyte GSH is determined by Beutler's method. Table 5 compares the glutathione determinations carried out on washed erythrocytes and on whole blood from three different control subjects. Glutathione levels in washed erythrocytes given by Beutler's method are lower than those found with Tietze's method; the values for whole human blood correspond with those reported by Tietze (1969). Although oxidized glutathione (GSSG) is included in the erythrocytic glutathione levels obtained with Tietze's method, it cannot explain the striking difference between the two methods, since GSSG accounts for less than $0.5 \%$ of the total erythrocyte glutathione content (Srivastava and Beutler, 1967; Tietze, 1969). Although Pihl, Eldjarn, and Bremer (1957) ruled out the possibility that mixed disulphides containing glutathione can serve as direct substrate for glutathione reductase, nevertheless a number of investigators have questioned the specificity of this enzyme (Icèn, 1967; Tietze, 1969). Furthermore, it has been shown that human erythrocyte glutathione reductase can catalyse the reduction of dihydrolipoic acid
(Scott, Duncan, and Ekstrand, 1963) and the release of GSH from the haemoglobin-GSH mixed disulphide (Srivastava and Beutler, 1970).

\section{Discussion}

The moderate decrease of GSH concentration in erythrocytes correlates significantly with increasing $\mathrm{Pb}-\mathrm{B}(\mathrm{r}=-0.423)$ but not with increasing Cd-B (Table 1; Figs 1 and 2). Despite the rather low correlation coefficient, the internal dose $(\mathrm{Pb}-\mathrm{B})$ response (\% of individuals with GSH $<\bar{X}-2$ SD of the controls) relationship shows that erythrocyte GSH concentration can be decreased already in the 'normal $\mathrm{Pb}-\mathrm{B}$ range' but only in a limited number of subjects. With increasing $\mathrm{Pb}-\mathrm{B}$ the relative number of affected subjects only slightly increases up to about 40 to $50 \%$ in the high $\mathrm{Pb}-\mathrm{B}$ range. In regard to erythrocytic GSH level the non-response internal dose of $\mathrm{Pb}$ in blood appeared to be 0.9-1.2 $\mu \mathrm{mol} / \mathrm{l}$ $(20-25 \mu \mathrm{g} / 100 \mathrm{ml})$. Hence it appears that the reliability of a threshold GSH value of $54 \mathrm{mg} / 100 \mathrm{ml}$ erythrocytes (Bonsignore et al., 1967) or $32.9 \mathrm{mg} / 100$ $\mathrm{ml}$ whole blood (Vasiliu et al., 1969) to differentiate between $\mathrm{Pb}$-intoxicated and normal individuals can be questioned. We conclude that the erythrocyte GSH concentration can hardly be used as a diagnostic or discriminating criterion for estimation of the degree of exposure to lead.

$\mathrm{Pb}$-ions are known to have affinity for -SH groups, less strongly however than do Hg-ions (Passow, 1970), and to form stable chelate complexes with sulphydryl containing compounds (Lenz and Martell, 1964; Doornbos and Faber, 1964). One of the adverse effects of lead on cellular metabolism arises from the interaction of $\mathbf{P b}$ with enzyme -SH groups in such a way that they are not available to certain enzymes that require free -SH group(s) for their activity, for example, enzymes involved in the biosynthesis of haem. In the living organism under most conditions this inhibition is apparently partial (Chisolm, 1971). The strong inactivating action of $\mathrm{Pb}$ on ALAD in 
erythrocytes, presumably through chelation of essential sulphydryl groups, is however as demonstrated by the present investigation not countered by the endogenous erythrocytic GSH concentration which at least with respect to $\mathrm{Pb}$ probably does not play a regulating role in the ALAD activity of erythrocytes. Even if $\mathrm{Pb}$ should act directly on endogenous GSH, the loss would represent no more than $0.5 \%$ for extreme cases of $\mathrm{Pb}$-exposed workers of our study population. Our results therefore support the hypothesis of Cartasegna et al. (1967), Vergnano et al. (1967), and Granick et al. (1973) that inhibition of ALAD in vivo by $\mathrm{Pb}$ is not due to decreased levels of endogenous erythrocytic GSH. Indeed, the ALAD activity in our study population remained highly inversely correlated with increasing $\mathbf{P b}-\mathbf{B}$ $(r=-0.748)$ when the erythrocyte GSH concentration was held constant, but on the contrary, the apparently significant correlation between ALAD activity and GSH level completely disappeared by keeping Pb-B constant (Table 1).

Lead-induced shortening of the life-span of mature erythrocytes has been studied in vivo and in vitro by investigating alterations in membrane properties, for example, changes in permeability to $\mathrm{K}^{+}$(Hernberg, 1967; Passow, 1970; Secchi, Alessio, and Cambiaghi, 1973) and in mechanical and osmotic fragility (Waldron, 1966). The presence of free membrane sulphydryl groups (Jacob and Jandl, $1962 a, b)$ and a relatively high endogenous GSH level (Prins and Loos, 1969) have been clearly demonstrated to be indispensable for the structural and functional integrity of erythrocytes. Much less attention however has been paid to possible interferences of $\mathrm{Pb}$ and $\mathrm{Cd}$ with erythrocytic enzyme systems known to be involved in the maintenance of a high endogenous GSH level, that is, the system of GSH regeneration and that of the continuous GSH resynthesis. The most frequently studied enzyme in the former system is G-6-PD, but its activity is measured in haemolysates. Our present in vivo investigation of GSH regeneration rate was performed however with intact erythrocytes that provide more or less normal physiological working conditions for the enzymes. The observed overall activity of the glutathione oxidation-reduction pathway showed clearly no impairment of the enzymatic reduction of GSSG $\rightarrow 2$ GSH in exposed workers with significantly increased $\mathrm{Pb}-\mathrm{B}$ and $\mathrm{Cd}-\mathrm{B}$ (subgroup II), since their initial GSH regeneration rate (first $15 \mathrm{~min}$ ) was identical with that of the control group (Fig. 3). Results of similar in vitro experiments in which control whole blood was incubated beforehand with $\mathrm{Pb}^{2+}$ or $\mathrm{Cd}^{2+}$, or both, reinforce this finding (Table 3). Although Rubino et al. (1963) observed in 30 lead-poisoned patients significant decreases in erythrocyte G-6-PD activity, and in the level and stability of GSH, their hypothesis that these changes were caused by the action of $\mathrm{Pb}$ on the oxidationreduction system of erythrocytes lacks confirmation from the literature. On the contrary, our conclusion that within the $\mathrm{Pb}-\mathrm{B}$ (and $\mathrm{Cd}-\mathrm{B}$ ) range reported in the present paper no impairment of the glutathione redox system occurs is supported by Saita and Lussana's (1971) clinical follow-up of an occupationally $\mathrm{Pb}$ intoxicated woman with erythrocytic G-6-PD deficiency, and by other studies on erythrocytes from $\mathrm{Pb}$-intoxicated workers showing no significant changes in G-6-PD (Molé et al., 1965; Shafer and Tague, 1970) or in glutathione reductase activity (Shafer and Tague, 1970). Similar results were obtained with experimentally lead-poisoned rabbits (Molé et al., 1965; Rogers et al., 1971). In spite of a significant decrease of erythrocytic G-6-PD activity in acute lead-poisoned rats, Erich and Waller (1967) concluded from their own investigations and those of others that the premature splenic sequestration of circulating erythrocytes in lead-intoxication is a consequence of disturbances in the erythrocyte membrane (formation of $\mathrm{Pb}$-complexes with membrane proteins) caused by lead rather than of changes in metabolism. Studies on enzymes and metabolism of erythrocytes from lead-intoxicated persons (Hernberg, Nurminen, and Hasan, 1967; Shafer and Tague, 1970) and experimentally lead-poisoned rabbits (Rogers et al., 1971) revealed that, apart from ALAD, the activities of many enzymes (among them methaemoglobin reductase, G-6-PD, 6-phosphogluconic dehydrogenase, pyruvate kinase, triose phosphate isomerase, glutathione reductase, and diaphorase) were not affected, nor the overall activities of the Embden-Meyerhof and hexose monophosphate shunt pathways.

An alternative explanation for the normally functioning GSH regeneration system in erythrocytes of workers with significantly increased $\mathrm{Pb}-\mathrm{B}$ and Cd-B, for example, those of subgroup II, might be that in spite of a $15 \%$ decrease, the endogenous erythrocyte GSH level still remains sufficiently high to regulate the normal physiological activity of the hexose monophosphate shunt pathway (Jacob and Jandl, 1966).

Unlike the inhibition in vitro by low $\mathrm{Cd}^{2+}$ concentrations, neither ALAD nor glutathione reductase seemed to be affected by a substantial increase of Cd-B in vivo (Table 1, Fig. 3). In vivo metallothionein (Nordberg et al., 1971) presumably acts within the erythrocytes as a Cd-chelating agent protecting both enzymes, whereas purified enzymes lack this protection. Haemoglobin, which also binds Cd (Carlson and Friberg, 1957; Nordberg et al. 1971), could at least partially be responsible also for such a protective effect (Icèn, 1967).

Since our results demonstrate that increased $\mathbf{P b}-\mathbf{B}$ does not impair the glutathione reductase system of erythrocytes, the moderate decrease in endogenous 
erythrocyte GSH found in $\mathrm{Pb}$-exposed workers could result from an inhibition by lead of the erythrocyte mechanism for glutathione synthesis. Recent experiments showed that human erythrocytes in whole blood may renew their whole GSH content in about six days (Bondi et al., 1973) by de novo glutathione synthesis in which two enzymes, $\gamma$-glutamylcysteine synthetase and glutathione synthetase, are involved (Prins and Loos, 1969). The activity of the former enzyme depends most probably on a sulphydryl group that is essential for the enzymatic activity, whereas the latter does not (Majerus et al., 1971).

Although little is known about the regulation of GSH synthesis in erythrocytes, it might be that small lasting disturbances of the in vivo activity of these enzymes induced by lead may have moderate drawbacks on GSH synthesis and consequently to some extent on the GSH depending defence mechanism of erythrocytes and on their life-span in cases of lead intoxication.

Another explanation for the observed GSH decrease might be that, in particular, lead catalyses the formation of Heinz-bodies. An increased prevalence of erythrocytes with Heinz-bodies has been observed in children living in the neighbourhood of lead processing plants (Ghelberg et al., 1966). The apparent participation of disulphides in Heinz-body formation has focused attention on the role of haemoglobin-GSH complexes (mixed disulphide with the readily accessible thiol group of cysteine-93 of the haemoglobin $\beta$-chain) in haemolytic disease (Jacob, Brain, and Dacie, 1968). Further experimental work is necessary to distinguish between these two hypotheses.

This work was supported by the Commission des Communautés Européennes-Project No. 6244-00/2/028.

We are grateful to Professor R. L. Zielhuis (Coronel Laboratory, Amsterdam) for his helpful comments and we thank Miss N. Girboux and Mr. T. Seminck for their skilful assistance.

\section{References}

Abdulla, M. and Haeger-Aronsen, B. (1973). Antagonistic effect of zinc in relatively high concentration on inhibition of ALA-dehydratase activity by heavy metals in vitro. IRCS International Research Communications System, (73-8) 8-14-1.

Barltrop, D. and Smith A. (1971). Interaction of lead with erythrocytes. Experientia, 27, 92-93.

Basecqz, J. M., Lauwerys, R. and Buchet, J. P. (1971). Etude comparative de divers tests biologiques d'exposition au plomb. Archives des Maladies Professionnelles, 32, 453-464.

Batolska, A. and Marinova, H. (1970). Modifications du glutathion chez les travailleurs d'une entreprise métallurgique minière. Archives des Maladies Professionnelles, 31, 117-122.

Beutler, E., Duron, O. and Kelly, B. M. (1963). Improved method for the determination of blood glutathione. Journal of Laboratory and Clinical Medicine, 61, 882-888.

- Robson, M. and Buttenwieser, E. (1957). The mechanism of glutathione destruction and protection in drug-sensitive and nonsensitive erythrocytes. In vitro studies. Journal of Clinical Investigation, 36, 617-628.

Bondi, E., Levy, J., Ben-Yoseph, Y., Hochberg, A. and Dimant, E. (1973). On the synthesis of glutathione in human blood cells in vitro. Israel Journal of Chemistry, 11, 573-586.

Bonsignore, B., Cartasegna, C., Ardoino, V. and Vergnano, C. (1967). Glutatione ridotto eritrocitario nel saturnismo. Lavoro Umano, 19, 97-102.

Bruenger, F. W., Stevens, W., and Stover, B. J. (1973). The association of ${ }^{210} \mathrm{~Pb}$ with constituents of erythrocytes. Health Physics, 25, 37-42.

Carlson, L. A. and Friberg, L. (1957). The distribution of cadmium in blood after repeated exposure. Scandinavian Journal of Clinical and Laboratory Investigation, 9, 67-70.

Cartasegna, C., Vergnano, C., and Ardoino, V. (1967). Livelli di glutatione ridotto e attività ALA-deidratasica nel sangue e nel fegato dopo trattamento con N-etilmaleimide. Bolletino della Societa Italiana de Biologia Sperimentale, 43, 1209-1210.

Chisolm, J. J. (1971). Lead poisoning. Scientific American, 24, 15-23.

Colucci, A. V., Hammer, D. I., Williams, M. E., Hinners, T. A., Pinkerton, C., Kent, J. L., and Love, G. L. (1973). Pollutant burdens and biological response. Archives of Environmental Health, 27, 151-154.

de Barreiro, O. L. C. (1967). 5-Aminolaevulinate hydrolyase from yeast. Isolation and purification. Biochimica et Biophysica Acta, 139, 479-486.

(1969). Effect of cysteine on 5-aminolaevulinate hydrolyase from liver in two cases of experimental intoxication. Biochemical Pharmacology, 18, 2267-2271.

Doornbos, D. A. and Faber, J. S. (1964). Studies on metal complexes of drugs, D-penicillamine and N-acetyl-Dpenicillamine. Pharmaceutisch Weekblad, 99, 289-309.

Erich, C. and Waller, H. D. (1967). Zum Verhalten von SH-Verbindungen in Erythrocyten nach in vivoVergiftung mit Schwermetallen und Arsen. Klinische Wochenschrift, 45, 983-986.

Ghelberg, N. W., Bretter, E., Costin, L., and Chitul, E. (1966). Investigations on the appearance of Heinz bodies under the influence of small lead concentrations in the atmosphere. Igiena, 15, 209-220.

Gibson, S. L. M. and Goldberg, A. (1970). Defects in haem synthesis in mammalian tissues in experimental lead poisoning and experimental porphyria. Clinical Science, 38, 63-72.

Granick, S. and Mauzerall, D. (1958). Porphyrin biosynthesis in erythrocytes. II. Enzymes converting $\delta$-aminolevulinic acid to coproporphyrinogen. Journal of Biological Chemistry, 232, 1119-1140.

Granick,J.L.,Sassa,S.,Granick,S.,Levere,R., and Kappas, A. (1973). Studies in lead poisoning. II. Correlation between the ratio of activated to inactivated $\delta$-aminolevulinic acid dehydratase of whole blood and the blood lead level. Biochemical Medicine, 8, 149-159. 
Granzoni, A. and Rhomberg, F. (1965). Hämolytische Krise bei Mangel an Glukose-6-phosphatdehydrogenase und Bleiintoxikation. Acta Haematologica, 34, 338-346.

Hapke, H. J. and Prigge, E. (1973). Interactions of lead and glutathione with delta-aminolevulinic acid dehydratase. Archiv für Toxikologie, 31, 153-161.

Heilmeyer, L. (1966). Disturbances in Heme Synthesis, p. 151. Thomas, Springfield, Illinois.

Hernberg, S. (1967). Life span, potassium fluxes and membrane ATPases of erythrocytes from subjects exposed to inorganic lead. Dissertation, WorkEnvironment-Health, 3, Suppl. 1, p. 74.

- , and Nikkanen, J. (1972). Effect of lead on $\delta$ aminolaevulinic acid dehydratase. A selective review. Pracovni lekařstvi, 24, 77-83.

- Nurminen, M., and Hasan, J. (1967). Oxygen and glucose consumption and lactate production of erythrocytes of workers exposed to inorganic lead. Internationales Archiv für Gewerbepathologie und Gewerbehygiene, 23, 117-126.

_- Tola, S., Nikkanen, J., and Valkonen, S. (1972). Erythrocyte $\delta$-aminolevulinic acid dehydratase in new lead exposure. A longitudinal study. Archives of Environmental Health, 25, 109-113.

Icèn, A. (1967). Glutathione reductase of human erythrocytes. Purification and properties. Scandinavian Journal of Clinical and Laboratory Investigation, Suppl. 96, 1-67.

Jacob, H. S., Brain, M. C., and Dacie, J. V. (1968). Altered sulfhydryl reactivity of hemoglobins and red blood cell membranes in congenital Heinz body hemolytic anemia. Journal of Clinical Investigation, 47, 2664-2677.

- , and Jandl, J. H. (1962a). Effects of sulfhydryl inhibition on red blood cells. I. Mechanism of hemolysis. Journal of Clinical Investigation, 41, 779-792.

,$--(1962 b)$. Effects of sulfhydryl inhibition on red blood cells. II. Studies in vivo. Journal of Clinical Investigation, 41, 1514-1523.

- - (1966). Effects of sulfhydryl inhibition on red blood cells. III. Glutathione in the regulation of the hexose monophosphate pathway. Journal of Biological Chemistry, 241, 4243-4250.

Jonderko, G. (1961). Diagnostic value of the determination of the blood glutathione level in chronic poisoning in human subjects. Polskie Archiwum Medycyny Wewnetrznej, 31, 647-655.

— , and Sroczyński, J. (1963). Behaviour of reduced glutathione concentration in blood in experimental lead poisoning in rabbits. Postepy Higieny $i$ Medycyny Doswiadszalnej, 17, 615-618.

Kao, R. L. C. and Forbes, R. M. (1973). Effects of lead on heme-synthesizing enzymes and urinary $\delta$-aminolevulinic acid in the rat. Proceedings of the Society for Experimental Biology and Medicine, 143, 234-237.

Kosower, N. S., Song, K.-R., and Kosower, E.M.(1969a) Glutathione. I. The methyl phenyldiazenecarboxylate (azoester) procedure for intracellular oxidation. Biochimica et Biophysica Acta, 192, 1-7.

(1969b). Glutathione. III. Biological aspects of the azoester procedure for oxidation within the normal human erythrocyte. Biochimica et Bio- physica Acta, 192, 15-22.

Lauwerys, R. R. and Buchet, J. P. (1973). Occupational exposure to mercury vapors and biological action. Archives of Environmental Health, 27, 65-68.

- - and Roels, H. A. (1973). Comparative study of effect of inorganic lead and cadmium on blood $\delta$-aminolevulinate dehydratase in man. British Journal of Industrial Medicine, 30, 359-364.

- - - - and Materne, D. (1974). Relationship between urinary $\delta$-aminolevulinic acid excretion and the inhibition of red cell $\delta$-aminolevulinate dehydratase by lead. Clinical Toxicology, 7, 383-388.

Lenz, G. R. and Martell, A. E. (1964). Metal chelates of some sulfur-containing amino acids. Biochemistry, 3, 745-750.

Lichtman, H. C. and Feldman, F. (1963). In vitro pyrrole and porphyrin synthesis in lead poisoning and iron deficiency. Journalof Clinical Investigation, 42, 830-839.

Majerus, P. W., Brauner, M. J., Smith, M. B., and Minnich, V. (1971). Glutathione synthesis in human erythrocytes. II. Purification and properties of the enzymes of glutathione biosynthesis. Journal of Clinical Investigation, 50, 1637-1643.

McIntire, M. S. and Angle, C. R. (1972). Air lead: Relation to lead in blood of black school children deficient in glucose-6-phosphate dehydrogenase. Science, 177, 520-522.

Millar, J. A., Cumming, R. L. C., Battistini, V., Carswell, F., and Goldberg, A. (1970). Lead and $\delta$-aminolaevulinic acid dehydratase levels in mentally retarded children and in lead-poisoned suckling rats. Lancet, 2, 695-598.

Molé, R., Lamanna, P., Pesaresi, C., and Rossi, A. (1965). Gli enzimi glicolitici del globulo rosso nel saturnismo umano e sperimentale. Folia Medica (Napoli), 48, 44-48.

Moore, M. R., Beattie, A. D., Thompson, G. G., and Goldberg, A. (1971). Depression of $\delta$-aminolaevulinic acid dehydratase activity by ethanol in man and rat. Clinical Science, 40, 81-88.

Nagai, T., Huse, T., and Saikawa, S. (1956). On the change of blood glutathione level in experimentally leadpoisoned rabbits. Journal of Science of Labour (Japan), 32, 390-403.

Nakao, K., Wada, O., and Yano, Y. (1968). $\delta$-Aminolevulinic acid dehydratase activity in erythrocytes for the evaluation of lead poisoning. Clinica Chimica Acta, 19, 319-325.

Nordberg, G. F., Piscator, M., and Nordberg, M. (1971). On the distribution of cadmium in blood. Acta Pharmacologica et Toxicologica, 30, 389-395.

Passow, H. (1970). In Effects of Metals on Cells, Subcellular Elements, and Macromolecules, edited by J. Maniloff, J. R. Coleman, and M. W. Miller, p. 291. Thomas, Springfield, Illinois.

Pihl, A., Eldjarn, L., and Bremer, J. (1957). On the mode of action of X-ray protective agents. III. The enzymatic reduction of disulfides. Journal of Biological Chemistry, 227, 339-345.

Prins, H. K. and Loos, J. A. (1969). Glutathione. In Biochemical Methods in Red Cell Genetics, edited by J. J. Yunis, pp. 115-137. Academic Press, New York and London. 
Roels, H. A., Buchet, J. P., and Lauwerys, R. R. (1974). Inhibition of human erythrocyte $\delta$-aminolevulinate dehydratase by lead. In vitro artifact or real phenomenon in vivo? Internationales Archiv für Arbeitsmedizin, 33, 277-284.

Rogers, L. E., Battles, N. D., Reimold, E. W., and Sartain, P. (1971). Erythrocyte enzymes in experimental lead poisoning. Archiv für Toxikologie, 28, 202-207.

Rubino, G. F., Coscia, G. C., Perrelli, G., and Parigi, A. (1963). Comportamento del glutatione del test di stabilità del glutatione e dell' attività glucosio-6fosfato-deidrogenasica nel saturnismo. Minerva Medica, 54, 930-932.

Saita, G. and Lussana, S. (1971). Intossicazione da piombo in portatrice de emazie fabiche. Medicina del Lavoro, 62, 22-27.

Scott, E. M., Duncan, J. W., and Ekstrand, V. (1963). Purification and properties of glutathione reductase of human erythrocytes. Journal of Biological Chemistry, 238, 3928-3933.

Secchi, G. C., Alessio, L., and Cambiaghi, G. (1973). $\mathrm{Na}^{+} / \mathrm{K}^{+}$ATPase activity of erythrocyte membranes in urban populations not occupationally exposed to lead. Archives of Environmental Health, 27, 399-400.

—, Erba, L., and Cambiaghi, G. (1974). Deltaaminolevulinic acid dehydratase activity of erythrocytes and liver tissue in man. Relationship to lead exposure. Archives of Environmental Health, 28, 130-132.

Shafer, A. W. and Tague, L. L. (1970). Effects of lead on red cell enzymes. Clinical Research, 18, 178.'

Shiraishi, A. (1952). Concentration of reduced glutathione in the blood of lead-poisoned persons. Nisshin Igaku, 39, 478-483.

Srivastava, S. K. and Beutler, E. (1967). Permeability of normal and glucose-6-phosphate dehydrogenasedeficient erythrocytes to glutathione. Biochemical and Biophysical Research Communications, 28, 659-664.

- - (1970). Glutathione metabolism of the erythrocyte. The enzymic cleavage of glutathione-haemoglobin preparations by glutathione reductase. Biochemical Journal, 119, 353-357.

Steiger, M. (1968). Die Bedeutung von Blei bei hereditären Erythrozytenanomalien. Schweizerische Zeitschrift für Unfallmedizin und Berufskrankheiten, 61, 199-221.
Tietze, F. (1969). Enzymic method for quantitative determination of nanogram amounts of total and oxidized glutathione: Applications to mammalian blood and other tissues. Analytical Biochemistry, 27, 502-522.

Tomio, J. M., Tuzman, V., and Grinstein, M. (1968). $\delta$-Aminolevulinate dehydratase from rat Harderian gland. European Journal of Biochemistry, 6, 84-87.

Vasiliu, A., Stavri, G., and Freund, S. (1969). Value of reduced glutathione determinations in workers exposed to lead. Revista Medico-chirurgicala $a$ societatii di Medici si Naturalisti diu Iasi, 73, 647-652.

Vens, M. D. and Lauwerys, R. (1972). Détermination simultanée du plomb et du cadmium dans le sang et l'urine par le couplage des techniques de chromatographie sur résine échangeuse d'ions et de spectrophotométrie d'absorption atomique. Archives des Maladies Professionnelles, 33, 97-105.

Vergnano, C., Cartasegna, C., and Bonsignore, D. (1967). Livelli di glutatione ridotto nella intossicazione sperimentale da piombo. Bolletino della Societa Italiana de Biologia Sperimentale, 43, 1099-1102.

Waldron, H. A. (1966). The anaemia of lead poisoning: A review. British Journal of Industrial Medicine, 23, 83-100.

Wilson, E. L., Burger, P. E., and Dowdle, E. B. (1972). Beef-liver 5-amino-levulinic acid dehydratase. Purification and properties. European Journal of Biochemistry, 29, 563-571.

Yawata, Y. and Tanaka, K. R. (1973). Studies on glutathione reductase and regeneration of reduced glutathione in normal human adult and cord red cells. Clinica Chimica Acta, 46, 267-275.

Zielhuis, R. L. (1973). Lead absorption and public health: An appraisal of hazards. In Proceedings of the International Symposium on Environmental Health, Aspects of Lead, organized jointly by CEC-EPA, 1972, Amsterdam. Edited by Commission of the European Communities, Centre for Information and Documentation, Luxembourg (Grand-Duché), 1973, pp. 631-653.

Received for publication 31 July 1974

Accepted for publication 29 October 1974 